\title{
Thermally reduced graphene/MXene film for enhanced Li-ion storage
}

\author{
Shuaikai Xu, ${ }^{[a]}$ Yohan Dall'Agnese, ${ }^{[a]}$ Junzhi Li, ${ }^{[a]}$ Yury Gogotsi, ${ }^{[a,}{ }^{[b]}$ and Wei Han*[a, c]
}

Abstract: Two-dimensional transition metal carbides called MXenes are emerging electrode materials for energy storage due to their metallic electrical conductivity and low ion diffusion barrier. In this work, we combined $\mathrm{Ti}_{2} \mathrm{CT}_{x}$ MXene with graphene oxide (GO) followed by a thermal treatment to fabricate flexible $\mathrm{rGO} / \mathrm{Ti}_{2} \mathrm{CT}_{\mathrm{r}}$ film, where electrochemically active $\mathrm{rGO}$ and $\mathrm{Ti}_{2} \mathrm{CT}_{\mathrm{r}}$ nanosheets impede the stacking of layers and synergistically interact producing ionically and electronically conducting electrodes. The effect of the thermal treatment on the electrochemical performance of $\mathrm{Ti}_{2} \mathrm{CT}_{\mathrm{x}}$ is evaluated. As anode for $\mathrm{Li}$-ion storage, the thermally treated $\mathrm{Ti}_{2} \mathrm{CT}_{\mathrm{r}}$ possesses a higher capacity in comparison to as-prepared $\mathrm{Ti}_{2} \mathrm{CT}_{\mathrm{x}}$. The freestanding hybrid $\mathrm{rGO} / \mathrm{Ti}_{2} \mathrm{CT}_{\mathrm{r}}$ films exhibit excellent reversible capacity $\left(700 \mathrm{mAh} \mathrm{g}^{-1}\right.$ at $\left.0.1 \mathrm{~A} \mathrm{~g} \mathrm{~g}^{-1}\right)$, cycling stability and rate performance. Additionally, flexible $\mathrm{rGO} / \mathrm{Ti}_{3} \mathrm{C}_{2} \mathrm{~T}_{\mathrm{r}}$ films are made using the same method and also present improved capacity. Therefore, this study provides a simple, yet effective, approach to combine rGO with different MXenes, which can enhance their electrochemical properties for Li-ion batteries.

\section{Introduction}

Development of high-performance electrochemical energy storage devices has attracted increasing attention with the growing use of renewable energy sources, ${ }^{[1-3]}$ and penetration of wearable devices into daily life. The Li-ion battery (LIB) is regarded as the most suitable candidate to satisfy energy storage needs due to its advanced development stage. ${ }^{[4-5]}$ Many research efforts aim to develop advanced materials with higher capacities and lifetimes than current graphite or lithium titanate anodes. ${ }^{[6]}$

[a] Dr. S. Xu, Dr. Y. Dall'Agnese, Dr. J. Li, Prof. Y. Gogotsi, Prof. W. Han Key Laboratory of Physics and Technology for Advanced Batteries (Ministry of Education)

Jilin University, Changchun 130012, (P.R. China)

E-mail:whan@jlu.edu.cn

[b] Prof. Y. Gogotsi

Department of Materials Science and Engineering, and A. J. Drexe Nanomaterials Institute

Drexel University, Philadelphia, Pennsylvania 19104, USA

E-mail: gogotsi@drexel.edu

[c] Prof W. Han

International Center of Future Science

Jilin University, Changchun 130012, (P.R. China)
Two-dimensional (2D) materials such as graphene, ${ }^{[7]}$ sulfides, ${ }^{[8,9]}$ nitrides, ${ }^{[10,11]}$ and oxides $^{[12,13]}$ have attracted considerable interest because of their unique and beneficial physical and chemical properties when used as LIB anode materials. However, limited electronic conductivity is an issue for many $2 \mathrm{D}$ materials. The largest family of highly conductive $2 \mathrm{D}$ materials is transition metal carbide/carbonitride labeled MXenes, which were discovered recently. ${ }^{[14]} \mathrm{MXene}$ are synthesized by selectively etching the $A$ ( $A l$, and other) layers from $M_{n+1} A X_{n}$ phases (where $M$ is an early transition metal, $X$ is carbon or nitrogen and $n=1-3$ ). When the A-layers are etched out, they are replaced by a combination of surface terminations such as $\mathrm{OH}, \mathrm{O}$ and $F$, therefore the correct chemical designation for MXenes is $M_{n+1} X_{n} T_{x}$ ( $T_{x}$ refers to surface functional groups). MXenes are emerging as a promising anode material for Li-ion batteries ${ }^{[15]}$ due to their metallic conductivity and $2 \mathrm{D}$ structure. Although $\mathrm{Ti}_{3} \mathrm{C}_{2} \mathrm{~T}_{\mathrm{x}}$ and $\mathrm{Ti}_{2} \mathrm{CT}_{\mathrm{x}}$ have good electrical conductivity ${ }^{[16]}$ and a low $\mathrm{Li}^{+}$diffusion barrier, ${ }^{[17]}$ their capacity as anodes is not high enough compared to $\mathrm{Sn}$, Si or other advanced nanomaterials. Assynthetized $\mathrm{Ti}_{3} \mathrm{C}_{2} \mathrm{~T}_{\mathrm{x}}$ and $\mathrm{Ti}_{2} \mathrm{CT}_{\mathrm{x}}$ have capacities around 100 $\mathrm{mAh} / \mathrm{g}$ at $1 \mathrm{C}$ rate, ${ }^{[18-20]}$ which limits their application as electrode materials. To improve the capacity of $\mathrm{Ti}_{3} \mathrm{C}_{2} \mathrm{~T}_{\mathrm{x}}$ anode, $\mathrm{Ti}_{3} \mathrm{C}_{2} \mathrm{~T}_{x}$ 'paper' was fabricated by filtering delaminated few-layer $\mathrm{Ti}_{3} \mathrm{C}_{2} \mathrm{~T}_{\mathrm{x}}$ colloidal solution, ${ }^{[20]}$ or producing hybrid $\mathrm{Ti}_{3} \mathrm{C}_{2} \mathrm{~T}_{\mathrm{x}} /$ carbon nanotubes electrodes. ${ }^{[21,22]}$ More recently, $\mathrm{Sn}(+\mathrm{IV})$-complexed ions decorating and pillaring highly conductive $\mathrm{Ti}_{3} \mathrm{C}_{2} \mathrm{~T}_{\mathrm{x}}$ electrodes were used to produce anodes for advanced LIBs with outstanding capacities ${ }^{[17,23]}$ Additionally, it is predicted by DFT calculation that $\mathrm{M}_{2} \mathrm{C}$ ( $\mathrm{M}=\mathrm{Sc}, \mathrm{Ti}, \mathrm{V}$, and $\mathrm{Cr}$ ) MXenes have gravimetric capacities over $400 \mathrm{~mA} \mathrm{~h} \mathrm{~g}^{-1}$, which is higher than the gravimetric capacity of graphite, and can be doubled by forming Li metal bilayers between MXene layers. ${ }^{[24]}$ Besides, the capacities of MXenes were predicted to significantly depend on the nature of surface terminal groups $(-\mathrm{F},-\mathrm{O}$ or $-\mathrm{OH}) .{ }^{[24-26]}$ As the thinnest and lightest MXene, $\mathrm{Ti}_{2} \mathrm{CT}_{\mathrm{x}}$, which is the closest to $\mathrm{Ti}_{3} \mathrm{C}_{2} \mathrm{~T}_{\mathrm{x}}$ in composition, has a higher theoretical capacity than $\mathrm{Ti}_{3} \mathrm{C}_{2} \mathrm{~T}_{\mathrm{x}}$ but lower conductivity.

Directly after synthesis, the electronic contact between the $\mathrm{Ti}_{2} \mathrm{CT}_{\mathrm{x}} \mathrm{MXene}$ blocks is poor due to the large size of the particles, resulting in isolated MXene blocks and limiting the electrochemical performance. This problem can be solved by introducing conductive "bridges" to connect $\mathrm{Ti}_{2} \mathrm{CT}_{\mathrm{x}}$ particles. 
Graphene, another important 2D material, has been widely used as an electrode for energy storage due to its good electronic conductivity, large theoretical specific surface area $\left(\sim 2630 \mathrm{~m}^{2} \mathrm{~g}\right.$ $\left.{ }^{1}\right)$, and superior mechanical properties. ${ }^{[26,27]}$ It has been hybridized with $\mathrm{Ti}_{3} \mathrm{C}_{2} \mathrm{~T}_{\mathrm{x}} \mathrm{MXene}$ for supercapacitor applications. ${ }^{[28]}$ Hence, by combining graphene with $\mathrm{Ti}_{2} \mathrm{CT}_{\mathrm{x}}$ it may be possible to improve the electrochemical performance of MXene-based anodes for Li-ion storage. ${ }^{[29,30]}$

In this work, flexible freestanding reduced graphene oxide ( $\mathrm{rGO}) / \mathrm{Ti}_{2} \mathrm{CT}_{\mathrm{r}}$ films were fabricated by vacuum-assisted filtration followed by thermal reduction under vacuum. During the thermal vacuum annealing, the surface terminal groups of $\mathrm{Ti}_{2} \mathrm{CT}_{\mathrm{x}}$ and
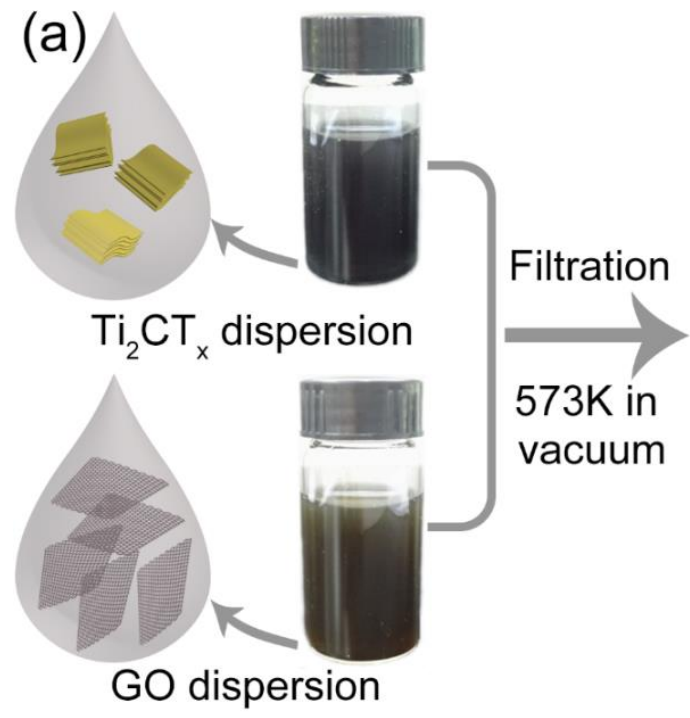

graphene oxide (GO) were removed at the same time, resulting in improved electrical conductivity and bridging between $\mathrm{Ti}_{2} \mathrm{CT}_{\mathrm{r}}$ and rGO nanosheets. In addition, the $\mathrm{Ti}_{2} \mathrm{CT}_{\mathrm{x}}$ particles acted as conductive spacers and impeded the agglomeration of rGO nanosheets. The $\mathrm{rGO} / \mathrm{Ti}_{2} \mathrm{CT}_{\mathrm{r}}$ films present enhanced electrochemical performance with high reversible capacity $(\sim 700$ $\mathrm{mAh} \mathrm{g}^{-1}$ at $0.1 \mathrm{~A} \mathrm{~g}^{-1}$ ), high coulombic efficiency, excellent cycling stability and rate performance. To demonstrate that this approach proposed for $\mathrm{rGO} / \mathrm{Ti}_{2} \mathrm{CT}_{\mathrm{r}}$ film anode can be applied to other MXenes, $r G O / \mathrm{Ti}_{3} \mathrm{C}_{2} \mathrm{~T}_{\mathrm{r}}$ films were also fabricated by the same method and showed an improved electrochemical performance for Li-ion storage.

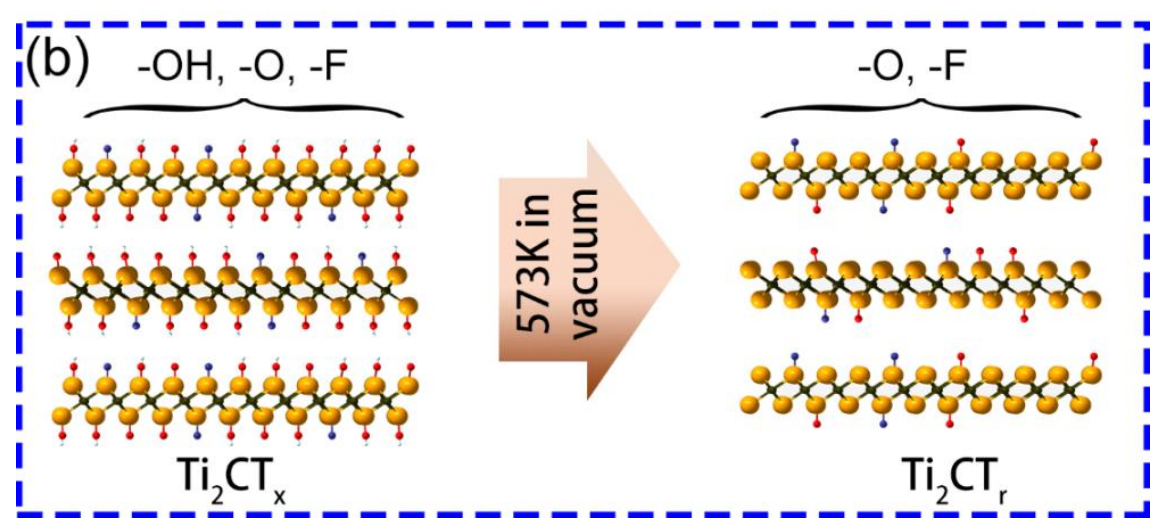

Figure 1. a) Schematic illustration of the fabrication process of the flexible $\mathrm{rGO} / \mathrm{Ti}_{2} \mathrm{CT}_{\mathrm{r}}$ film and the digital photograph of the flexible rGO/Ti ${ }_{2} \mathrm{CT}$ film. b) $\mathrm{Schematic}$ illustration of the surface modification process of $\mathrm{Ti}_{2} \mathrm{CT}_{\mathrm{x}}$

\section{Results and Discussion}

The flexible freestanding $\mathrm{rGO} / \mathrm{Ti}_{2} \mathrm{CT}_{\mathrm{r}}$ films were produced following the process shown in Figure 1a. The $\mathrm{rGO} / \mathrm{Ti}_{2} \mathrm{CT}_{\mathrm{r}}$ films were fabricated by vacuum-assisted filtration followed by thermal reduction at $573 \mathrm{~K}$ for $5 \mathrm{~h}$ under vacuum. During the thermal treatment process, the interlayer water and $-\mathrm{OH}$ terminal groups on the surface of $\mathrm{Ti}_{2} \mathrm{CT}_{x}$ MXene were concomitantly removed (Figure 1b). To achieve the best flexibility and mechanical properties of $\mathrm{rGO} / \mathrm{Ti}_{2} \mathrm{CT}_{r}$ films, the weight ratio of $\mathrm{rGO}: \mathrm{Ti}_{2} \mathrm{CT}_{r}$ was 
optimized and found to be 3:1 (details not shown in this work). Therefore, $\mathrm{rGO} / \mathrm{Ti}_{2} \mathrm{CT}_{\mathrm{r}}$ films with the weight ratio of $3: 1$ were fabricated and characterized hereafter.

As shown in Figure 2a, after etching of $\mathrm{Al}$ from $\mathrm{Ti}_{2} \mathrm{AIC}$ for $24 \mathrm{~h}$, the obtained $\mathrm{Ti}_{2} \mathrm{CT}_{\mathrm{x}}$ has a $2 \mathrm{D}$ layered structure, where the $\mathrm{Ti}_{2} \mathrm{CT}_{\mathrm{x}}$ layers were stacked into lamellas, indicating the successful etching. As shown in Figure S1a, after thermal reduction under vacuum, the $\mathrm{Ti}_{2} \mathrm{CT}_{\mathrm{r}}$ maintained $2 \mathrm{D}$ layered structure. The fewlayer GO nanosheets present flat flake-like morphology (Figure S1b), but after thermal reduction under a vacuum, rGO nanosheets present a wrinkled morphology as shown in Figure $2 \mathrm{~b}$ which is caused by the removal of oxygen-containing functional group $(-\mathrm{OH})$ from its surface. The rGO nanosheets possess a large lateral size and are a few layers thick. As a characteristic feature of rGO nanosheets, the presence of wrinkles and folds benefit the Li-ion transfer into rGO film. To further enhance the accessibility of the Li-ion to the film electrode and improve its electrochemical performance, $\mathrm{Ti}_{2} \mathrm{CT}_{\mathrm{x}}$ powders were introduced as conductive spacers between the $\mathrm{rGO}$ nanoflakes to produce flexible $\mathrm{rGO} / \mathrm{Ti}_{2} \mathrm{CT}_{\mathrm{r}}$ films, whose typical cross-sectional FESEM images are shown in Figure $2 \mathrm{~d}$, e. $\mathrm{rGO} / \mathrm{Ti}_{2} \mathrm{CT}_{\mathrm{r}}$ films possess more open structure than pure rGO (Figure S1c) or $\mathrm{GO} / \mathrm{Ti}_{2} \mathrm{CT}_{x}$ (Figure 2c) films due to the impeded stacking of $\mathrm{rGO}$ nanosheets by the embedded $\mathrm{Ti}_{2} \mathrm{CT}_{\mathrm{r}}$ particles and the thermal reduction process under vacuum. Figure S1d shows the top view FESEM image of the $\mathrm{rGO} / \mathrm{Ti}_{2} \mathrm{CT}_{\mathrm{r}}$ films. Both the wrinkles and folds of the graphene and the embedded $\mathrm{Ti}_{2} \mathrm{CT}_{\mathrm{r}}$ particles were clearly observed. The results of the corresponding elemental mapping of $\mathrm{Ti}$ and $\mathrm{C}$ in Figure $\mathrm{S} 1 \mathrm{e}, \mathrm{f}$ indicated that the $\mathrm{Ti}_{2} \mathrm{CT}_{\mathrm{r}}$ particles were uniformly distributed into the hybrid $\mathrm{rGO} / \mathrm{Ti}_{2} \mathrm{CT}_{\mathrm{r}}$ films. From Figure $2 \mathrm{f}$, it can be observed that $\mathrm{Ti}_{2} \mathrm{CT}_{\mathrm{r}}$ particles are surrounded by wrinkled $\mathrm{rGO}$ nanosheets, improving the conductivity between distant $\mathrm{Ti}_{2} \mathrm{CT}_{\mathrm{r}}$ blocks. The measured BET specific surface areas of the $\mathrm{GO} / \mathrm{Ti}_{2} \mathrm{CT}_{\mathrm{x}}$ and $\mathrm{rGO} / \mathrm{Ti}_{2} \mathrm{CT}_{\mathrm{r}}$ films were 127 and $270 \mathrm{~m}^{2} \mathrm{~g}^{-1}$, respectively (Figure $\mathrm{S} 1 \mathrm{~g}$ ). The increase of the BET-specific surface area is mainly attributed to the pore opening due to the gases released from rGO during reduction under vacuum. The pore width distributions of $\mathrm{rGO} / \mathrm{Ti}_{2} \mathrm{CT}_{\mathrm{r}}$ films were evaluated by the $\mathrm{BJH}$ method, and the pore size was determined to be around 3 $\mu \mathrm{m}$ (Figure S1h and pores seen in Fig. 2e), which ensured a high ion-accessible surface area and low ion transport resistance.
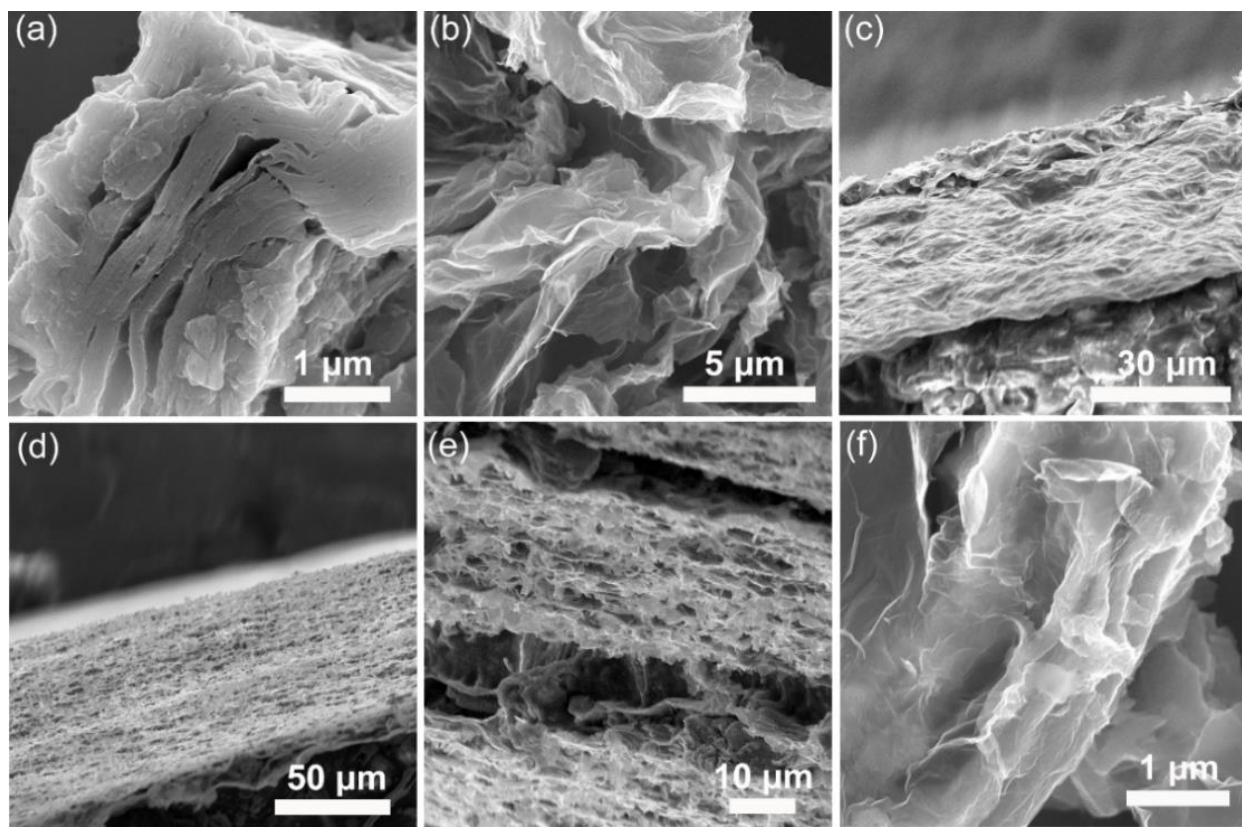

Figure 2. FESEM images of a) $\mathrm{Ti}_{2} \mathrm{CT}_{x}$ and b) rGO nanosheets. c) FESEM cross section image of a hybrid GO/Ti $2 \mathrm{CT}_{x}$ film. d) Low- and e) high-magnification FESEM cross section images of a hybrid $\mathrm{rGO} / \mathrm{Ti}_{2} \mathrm{CT}_{\mathrm{r}}$ film. f) High magnification FESEM image of $\mathrm{Ti}_{2} \mathrm{CT}_{\mathrm{r}}$ particles coated with rGO nanosheets. 

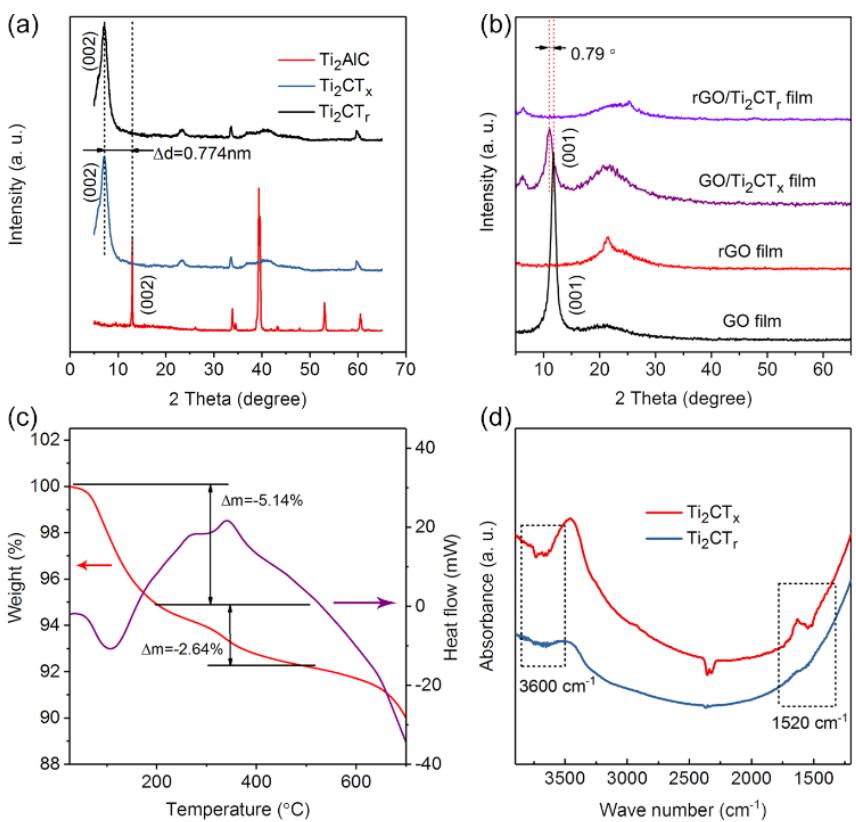

Figure 3. a) XRD patterns of $\mathrm{Ti}_{2} \mathrm{AIC}$ before and after etching using $\mathrm{HCl}+\mathrm{LiF}$ solution, and $\mathrm{Ti}_{2} \mathrm{CT}_{\mathrm{r}}$. b) XRD patterns of pure $\mathrm{GO}$, rGO film, hybrid $\mathrm{GO} / \mathrm{Ti}_{2} \mathrm{CT}_{\mathrm{x}}$, and $\mathrm{rGO} / \mathrm{Ti}_{2} \mathrm{CT}_{\mathrm{r}}$ film. c) $\mathrm{TG}$ and $\mathrm{DSC}$ curves of $\mathrm{Ti}_{2} \mathrm{CT}_{\mathrm{x}}$ from room temperature to $700{ }^{\circ} \mathrm{C}$ in argon atmosphere. d) FT-IR spectra of $\mathrm{Ti}_{2} \mathrm{CT}_{x}$ before and after thermal treatment.
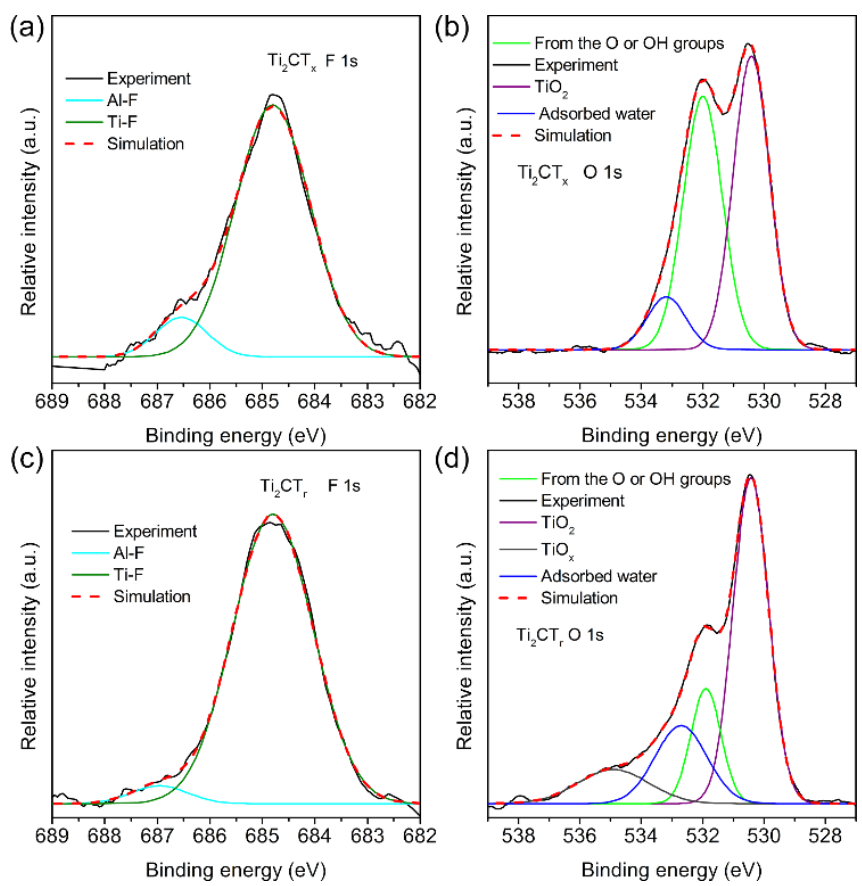

Figure 4. High-resolution XPS spectra of $\mathrm{Ti}_{2} \mathrm{CT}_{x}$ and $\mathrm{Ti}_{2} \mathrm{CT}_{r}$ in the $\mathrm{F} 1 \mathrm{~s}(\mathrm{a}, \mathrm{c})$ and $\mathrm{O} 1 \mathrm{~s}(\mathrm{~b}, \mathrm{~d})$ regions.

The phase composition of the materials was characterized by X-ray powder diffraction. When comparing the XRD patterns of the $\mathrm{Ti}_{2} \mathrm{AIC}$ powders before and after $\mathrm{HCl}+\mathrm{LiF}$-etching (Figure 3a), it is clear that the (002) peak, which was initially at $\approx 13.0^{\circ} 2 \theta$, broadened and shifted to a lower angle of $\approx 7.1^{\circ} 2 \theta$ after etching treatment, indicating that it shifted to a larger $d$ spacing $(\Delta d=0.774$ $\mathrm{nm})$. The peak of $\mathrm{Ti}_{2} \mathrm{AIC}$ at $\approx 39.2^{\circ} 2 \theta$ disappeared, suggesting the complete etching of $\mathrm{Al}$ from $\mathrm{Ti}_{2} \mathrm{AIC}$. Furthermore, the interlayer $\mathrm{d}$ spacing of $\mathrm{HCl}+\mathrm{LiF}$-etched $\mathrm{Ti}_{2} \mathrm{CT}_{\mathrm{x}}$ is much larger than that of the HF-etched $\mathrm{Ti}_{2} \mathrm{CT}_{\mathrm{x}}{ }^{[16,31]}$ The large shifts are suggestive of the presence of water, and possibly cations $\left(\mathrm{Li}^{+}, \mathrm{H}^{+}\right)$, between the hydrophilic and negatively charged $\mathrm{Ti}_{2} \mathrm{CT}_{\mathrm{x}}$ layers, similarly than

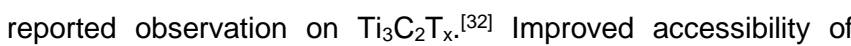
interlayer spacing in $\mathrm{HCl}+\mathrm{LiF}$-etched $\mathrm{Ti}_{2} \mathrm{CT}_{\mathrm{x}}$ is expected to the intercalation of $\mathrm{Li}$ ions, improving the electrochemical capacity of the anode. The almost unchanged XRD profile of $\mathrm{Ti}_{2} \mathrm{CT}_{\mathrm{r}}$ compared with $\mathrm{Ti}_{2} \mathrm{CT}_{\mathrm{x}}$ showed that the MXene phase didn't change during the thermal treatment process. As shown in Figure $3 b$, for pure GO film, a broad diffraction peak at $\approx 10.1^{\circ} 2 \theta$ is the typical peak corresponding to the layer-to-layer distance (dspacing) of about $0.83 \mathrm{~nm}$. However, after thermal reduction, the peak at $\approx 10.1^{\circ} 2 \theta$ disappears, indicating a reduction of $\mathrm{GO}$ to form rGO film. The peak (001) at $\approx 10.1^{\circ} 2 \theta$ of $\mathrm{GO} / \mathrm{Ti}_{2} \mathrm{CT}_{\mathrm{x}}$ significantly shifted to the lower position and the half-peak width increased after introduction of $\mathrm{Ti}_{2} \mathrm{CT}_{\mathrm{x}}$ between $\mathrm{GO}$ nanosheets. This can be attributed to the fact that the embedded $\mathrm{Ti}_{2} \mathrm{CT}_{\mathrm{x}}$ prevent the ordering of stacked GO nanosheet. A similar phenomenon was also observed for $\mathrm{rGO} / \mathrm{Ti}_{2} \mathrm{CT}_{\mathrm{r}}$ film comparing with $\mathrm{rGO}$ film, where the half-peak width also increased, demonstrating the successful combination of rGO nanosheets and $\mathrm{Ti}_{2} \mathrm{CT}_{\mathrm{r}}$ particles.

The surface structure is crucial for the electrochemical performance of MXene and thus several characterization techniques were applied. Thermogravimetric-differential scanning calorimetry (TG-DSC) analysis of $\mathrm{HCl}+\mathrm{LiF}$-etched $\mathrm{Ti}_{2} \mathrm{CT}_{\mathrm{x}}$ particles was carried out from room temperature to $700^{\circ} \mathrm{C}$ in argon atmosphere (Figure 3c). The surface of as-prepared $\mathrm{Ti}_{2} \mathrm{CT}_{\mathrm{x}}$ is known to be terminated with $\mathrm{F}$ and/or $\mathrm{OH}$. At high temperature, the $-\mathrm{OH}$ groups are lost or replaced by $-\mathrm{O}$. It can be seen that the mass of $\mathrm{Ti}_{2} \mathrm{CT}_{\mathrm{x}}$ decreased with increased temperature. A weight loss of $5.14 \%$ in the TG curve occurred from room temperature to about $200^{\circ} \mathrm{C}$, which is due to the loss of physically adsorbed water and residual acid on $\mathrm{Ti}_{2} \mathrm{CT}_{\mathrm{x}}$ surface. ${ }^{[33]}$ The second stage weight loss of $2.64 \%$ from $200^{\circ} \mathrm{C}$ to $515^{\circ} \mathrm{C}$ is caused by the loss of $-\mathrm{OH}$ groups attached on $\mathrm{Ti}_{2} \mathrm{CT}_{\mathrm{x}}$ surface. ${ }^{[34]}$ Based on the results of TG-DSC analysis, the surface $-\mathrm{OH}$ groups in $\mathrm{Ti}_{2} \mathrm{CT}_{\mathrm{x}}$ can be eliminated by thermal reduction, similar to $\mathrm{Ti}_{3} \mathrm{C}_{2} \mathrm{~T}_{\mathrm{x}}{ }^{[26]}$ To further confirm the release of $-\mathrm{OH}$ terminal groups by calcination at $300^{\circ} \mathrm{C}$, the Fourier transform infrared (FT-IR) measurement was also carried out for $\mathrm{Ti}_{2} \mathrm{CT}_{\mathrm{x}}$ before and after thermal treatment at $300^{\circ} \mathrm{C}$ 
under vacuum (Figure 3d). The peaks of the FT-IR spectra of $\mathrm{Ti}_{2} \mathrm{CT}_{\mathrm{x}}$ before thermal treatment at $\sim 3600$ and $\sim 1520 \mathrm{~cm}^{-1}$ confirm the existence of $-\mathrm{OH}$ or strongly coordinated $\mathrm{H}_{2} \mathrm{O}$ between $\mathrm{Ti}_{2} \mathrm{CT}_{x}$ layers. After thermal reduction, these peaks weakened or disappeared, suggesting that the terminal $-\mathrm{OH}$ could be efficiently removed by calcination at $300^{\circ} \mathrm{C}$ under vacuum. Oxygen terminal groups are preferred in Li-ion batteries. ${ }^{[24]}$ XPS was used to characterize the chemical state of the $\mathrm{Ti}_{2} \mathrm{CT}_{\mathrm{x}}$ and $\mathrm{Ti}_{2} \mathrm{CT}_{\mathrm{r}}$ (Figure S2). The XPS spectra of $\mathrm{Ti}_{2} \mathrm{CT}_{\mathrm{x}}$ confirmed that the Al was removed and the surface was terminated by oxygen-containing functional groups $(-\mathrm{OH},-\mathrm{O}$ and $-\mathrm{F})$. As shown in Figure 4a and $\mathrm{c}$, the $\mathrm{Ti}_{2} \mathrm{CT}_{\mathrm{x}}$ and $\mathrm{Ti}_{2} \mathrm{CT}_{\mathrm{r}}$ samples all contain a large amount of $-\mathrm{F}$ terminated $\mathrm{Ti}$. The intensity of the $\mathrm{Ti}-\mathrm{F}$ peaks almost unchanged after thermal treatment, indicating the amount of $-\mathrm{F}$ surface group remains unchanged. It was noticed that traces of $\mathrm{AlF}_{3}$ salt were present after $\mathrm{Ti}_{2} \mathrm{AlC}$ phase etching. For $\mathrm{Ti}_{2} \mathrm{CT}_{x}$, a high-resolution spectrum in the $\mathrm{O} 1 \mathrm{~s}$ region (Figure $4 \mathrm{~b}$ ) could be fit by peaks at $530.5,531.9$ and $533.0 \mathrm{eV}$. The component centered at $530.5 \mathrm{eV}$ is consistent with oxygen in $\mathrm{TiO}_{2}$. The component centered at $531.9 \mathrm{eV}$ likely arises from $\mathrm{O}$ or $\mathrm{OH}$ groups bound to the surface of the MXene layers. The peak centered at $533.0 \mathrm{eV}$ can be attributed to strongly adsorbed water. These peaks are also observed in the high-resolution spectrum of $\mathrm{Ti}_{2} \mathrm{CT}_{\mathrm{r}}$ in the $\mathrm{O} 1 \mathrm{~s}$ region (Figure $4 \mathrm{~d}$ ). The intensity of the peaks at 530.5 and 532.9 $\mathrm{eV}$ was almost unchanged in comparison with that of $\mathrm{Ti}_{2} \mathrm{CT}_{\mathrm{x}}$. However, the peak at $531.9 \mathrm{eV}$ obviously decreases, which can be attributed to the removal of $-\mathrm{OH}$ surface group. Additionally, a peak at $535.0 \mathrm{eV}$ appears, which likely arises from the formation $\mathrm{TiO}_{\mathrm{x}}$. The high-resolution XPS spectra in the $\mathrm{F}$ and $\mathrm{O}$ regions demonstrated that the $-\mathrm{OH}$ surface groups were effectively removed after thermal treatment, and MXene layers with mixed oxygen/fluorine terminations were formed. ${ }^{[35]}$ This finding is consistent with the results of TG-DSC and FT-IR analyses.

The electrochemical performance of the $\mathrm{rGO} / \mathrm{Ti}_{2} \mathrm{CT}_{\mathrm{r}}$ film was evaluated by tests in Li-ion half-cells, in which the $\mathrm{rGO} / \mathrm{Ti}_{2} \mathrm{CT}_{\mathrm{r}}$ films served as the working electrodes and Li metal foils acted as both counter and reference electrodes. Firstly, the effect of the thermal treatment on the electrochemical performance of $\mathrm{Ti}_{2} \mathrm{CT}_{x}$ is evaluated. As shown in Figure $\mathrm{S} 3 \mathrm{a}$ and b, broad reversible peaks were observed for both $\mathrm{Ti}_{2} \mathrm{CT}_{\mathrm{x}}$ and $\mathrm{Ti}_{2} \mathrm{CT}_{\mathrm{r}}$ at $1.68 \mathrm{~V}$ vs $\mathrm{Li}^{+} / \mathrm{Li}$ during lithiation and delithiation in cycles from 2nd to 6th Because the chemically adsorbed water or $-\mathrm{OH}$ terminations on surface of $\mathrm{Ti}_{2} \mathrm{CT}_{\mathrm{x}}$ were removed, these peaks can be tentatively assigned to the following redox intercalation reaction (Equation 1): $:[18]$

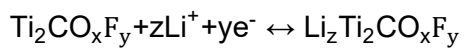

(a)

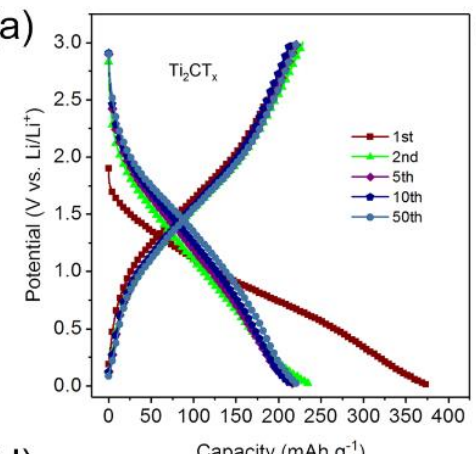

(d)

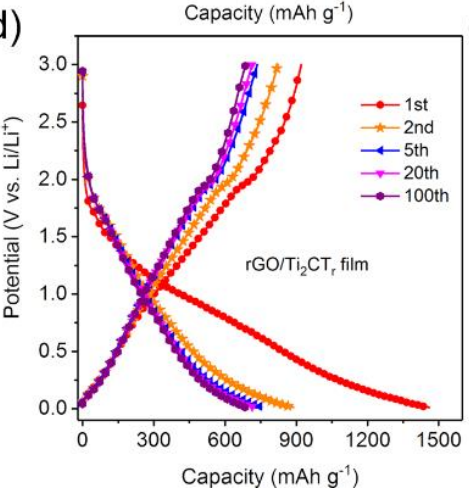

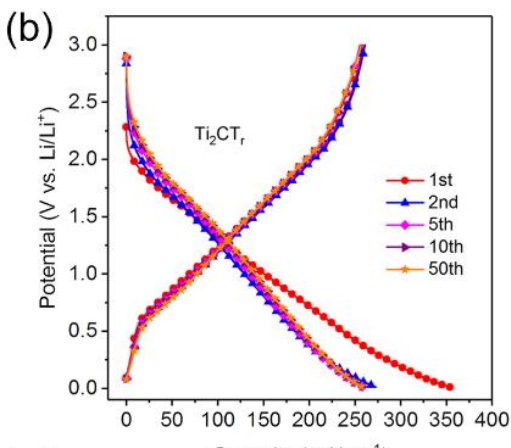

$(\mathrm{e})_{150}$

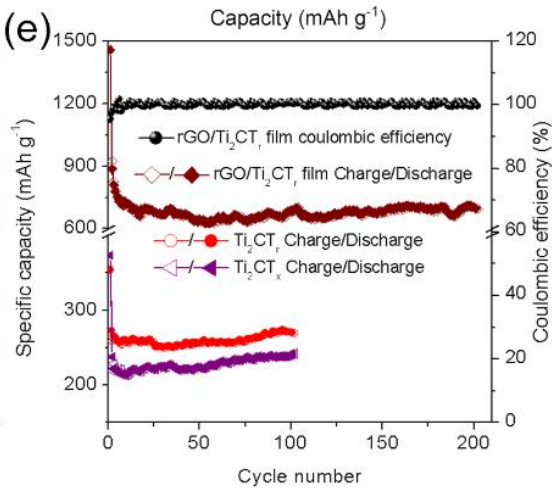

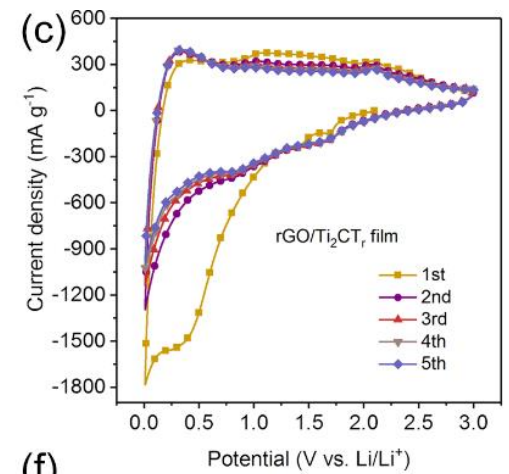

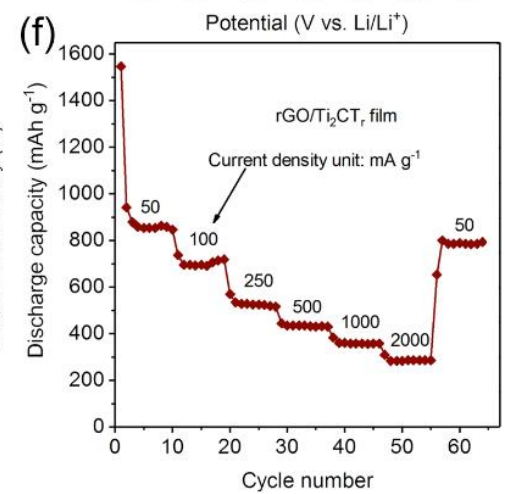

Figure 5. a) Charge/discharge profiles of $\mathrm{Ti}_{2} \mathrm{CT}_{\mathrm{x}}$ at current density of $0.1 \mathrm{~A} \mathrm{~g}^{-1}$. b) Charge/discharge profiles of $\mathrm{Ti}_{2} \mathrm{CT}_{\mathrm{r}}$ at current density of $0.1 \mathrm{Ag}^{-1}$. c) $\mathrm{CV}$ curves of $\mathrm{rGO} / \mathrm{Ti}_{2} \mathrm{CT}_{\mathrm{r}}$ film at a scan rate of $0.5 \mathrm{mV} \mathrm{s}^{-1}$. d) Charge-discharge profiles of $\mathrm{rGO} / \mathrm{Ti}_{2} \mathrm{CT}_{\mathrm{r}}$ film at different cycles with a current density of $0.1 \mathrm{~A} \mathrm{~g}^{-1}$. e) $\mathrm{Cycling}$ performance of $\mathrm{Ti}_{2} \mathrm{CT}_{x}, \mathrm{Ti}_{2} \mathrm{CT}_{r}$ and $\mathrm{rGO} / \mathrm{Ti}_{2} \mathrm{CT}_{\mathrm{r}}$ film at a current density of $0.1 \mathrm{~A} \mathrm{~g}^{-1}$. f) Rate performance of hybrid $\mathrm{rGO} / \mathrm{Ti}_{2} \mathrm{CT}_{\mathrm{r}}$ film electrode. 
Figure $5 \mathrm{a}$ and $\mathrm{b}$ show the GCD curves of $\mathrm{Ti}_{2} \mathrm{CT}_{\mathrm{x}}$ and $\mathrm{Ti}_{2} \mathrm{CT}_{\mathrm{r}}$ at a current density of $0.1 \mathrm{~A} \mathrm{~g}^{-1}$. The capacity loss in the first cycle can be attributed to the formation of solid electrolyte interphase (SEI) layer at potentials below $0.9 \mathrm{~V}$ vs. $\mathrm{Li}^{+} / \mathrm{Li}$. In the first cycle $\mathrm{Ti}_{2} \mathrm{CT}_{\mathrm{x}}$ shows higher capacity loss than $\mathrm{Ti}_{2} \mathrm{CT}_{\mathrm{r}}$, which is attributed to the presence of $-\mathrm{OH}$ groups and intercalated water in $\mathrm{Ti}_{2} \mathrm{CT}_{\mathrm{x}}$, leading to irreversible reaction during the first cycle. There is no obvious capacity loss after 100 cycles (Figure 5e) at current density of $0.1 \mathrm{~A} \mathrm{~g}^{-1}$, revealing a good reversibility. As shown in Figure S3c, it can be observed that the redox peaks of $\mathrm{Ti}_{2} \mathrm{CT}_{\mathrm{r}}$ broadened compared to that of $\mathrm{Ti}_{2} \mathrm{CT}_{\mathrm{x}}$, which is due to the removal of terminal $-\mathrm{OH}$ groups, increasing the number of active sites and possibly promoting the $\mathrm{Li}$ ions transport. As a result, $\mathrm{Ti}_{2} \mathrm{CT}_{\mathrm{r}}$ presented an improved capacity of $263 \mathrm{mAh} \mathrm{g}^{-1}$ (Figure S3d), which is higher than that of $\mathrm{Ti}_{2} \mathrm{CT}_{\mathrm{x}}\left(212 \mathrm{mAh} \mathrm{\textrm {g } ^ { - 1 }}\right)$. The improved electrochemical performance can be attributed to the enhanced electrical conductivity benefiting from the lower terminated surface group concentration after surface modification treatment. ${ }^{[24]}$ Furthermore, in order to verify the good electrochemical performance of $\mathrm{Ti}_{2} \mathrm{CT}_{\mathrm{r}}$ in comparison with $\mathrm{Ti}_{2} \mathrm{CT}_{\mathrm{x}}$, electrochemical impedance spectroscopy (EIS) was carried out using lithiated electrodes. Figure S4a compares the Nyquist plots of $\mathrm{Ti}_{2} \mathrm{CT}_{\mathrm{r}}$ and $\mathrm{Ti}_{2} \mathrm{CT}_{\mathrm{x}}$. The typical characteristics of their Nyquist plots are a semicircle in the high- medium-frequency range and a sloping straight line in the low-frequency range. The diameter of the semicircle of $\mathrm{Ti}_{2} \mathrm{CT}_{\mathrm{r}}$ is much smaller than that of $\mathrm{Ti}_{2} \mathrm{CT}_{\mathrm{x}}$, indicating that $\mathrm{Ti}_{2} \mathrm{CT}_{\mathrm{r}}$ possesses lower charge transfer resistance. The increased number of electrochemically active sites on $\mathrm{Ti}_{2} \mathrm{CT}_{\mathrm{r}}$ due to the removal of $-\mathrm{OH}$ terminations promoted the contact between the electrode material and electrolyte, causing a more effective charge-transfer process.

In the cyclic voltammetry (CV) profiles (Figure $5 \mathrm{c}$ ) of $\mathrm{rGO} / \mathrm{Ti}_{2} \mathrm{CT}_{\mathrm{r}}$ film, no obvious lithiation and delithiation peaks were observed, because of the introduction of rGO nanosheets ${ }^{[34]}$. The irreversible broad peak observed at $0.4 \mathrm{~V} \mathrm{vs}$. $\mathrm{Li}^{+} / \mathrm{Li}$ during lithiation process in the first cycle is probably caused by the formation of SEI and possibly an irreversible reaction between $\mathrm{Li}$ ion and electrode materials $\left(\mathrm{Ti}_{2} \mathrm{CT}_{\mathrm{r}}\right.$ or oxygen-containing functional groups on the rGO nanosheets). The charge/discharge profiles of the $\mathrm{rGO} / \mathrm{Ti}_{2} \mathrm{CT}_{\mathrm{r}}$ film are presented in Figure $5 \mathrm{~d}$, which are measured between 0.01 and $3 \mathrm{~V}$ at a current density of $0.1 \mathrm{~A} \mathrm{~g}^{-1}$.
A long sloping voltage region over the range from 1.8 to $0.3 \mathrm{~V}$ can be attributed to the constant lithiation/delithiation process in $\mathrm{rGO} / \mathrm{Ti}_{2} \mathrm{CT}_{\mathrm{r}}$ electrodes. In this work, gravimetric capacities are used to evaluate the performance of electrode materials. In the first cycle (Figure $5 e$ ), the discharge capacity of the $\mathrm{rGO} / \mathrm{Ti}_{2} \mathrm{CT}_{\mathrm{r}}$ film electrode is $1460 \mathrm{mAh} \mathrm{g}^{-1}$, while its charge capacity is 920 $\mathrm{mAh} \mathrm{g}^{-1}$, resulting in coulombic efficiency of $63 \%$, which is higher than that of pure rGO film (42\%, Figure S4b). The higher coulombic efficiency can be attributed to the impeded stacking of rGO nanosheets due to the introduction of $\mathrm{Ti}_{2} \mathrm{CT}_{\mathrm{r}}$ particles. The $\mathrm{rGO} / \mathrm{Ti}_{2} \mathrm{CT}_{\mathrm{r}}$ film showed coulombic efficiencies near $100 \%$ and stable cycle performance after 5 cycles. At the 100th cycle, a reversible capacity of $700 \mathrm{mAh} \mathrm{g}^{-1}$ can still be retained, which is much larger than that of the graphene film electrode ${ }^{[36]}$ and $\mathrm{Ti}_{2} \mathrm{CT}_{\mathrm{r}}$ (263 $\left.\mathrm{mAh} \mathrm{g}^{-1}\right)$ studied in this work.

The enhanced electrochemical performance of porous $\mathrm{rGO} / \mathrm{Ti}_{2} \mathrm{CT}_{\mathrm{r}}$ film can be related to a few occurrences. During the thermal reduction process, the surface terminal groups of $\mathrm{Ti}_{2} \mathrm{CT}_{\mathrm{x}}$ and $\mathrm{GO}$ can be removed at the same time, resulting in good electronic contact between $\mathrm{Ti}_{2} \mathrm{CT}_{\mathrm{r}}$ and $\mathrm{rGO}$ nanosheets. There is no polymer binder additive needed as $\mathrm{rGO}$ acts as a conductive binder to tightly link the separated layers of $\mathrm{Ti}_{2} \mathrm{CT}_{\mathrm{r}}$ and connect the separated $\mathrm{Ti}_{2} \mathrm{CT}_{\mathrm{r}}$ particles, improving the conductivity of the anode. If there is a volume change of $\mathrm{Ti}_{2} \mathrm{CT}_{\mathrm{r}}$ during the charge/discharge process, the suitable mechanical properties of rGO would allow to retain the electric contact. In addition, the $\mathrm{Ti}_{2} \mathrm{CT}_{\mathrm{r}}$ particles could impede the agglomeration of $\mathrm{rGO}$ nanoflakes. From Figure S4a, it can be observed that $\mathrm{rGO} / \mathrm{Ti}_{2} \mathrm{CT}_{\mathrm{r}}$ has a lower charge-transfer resistance in comparison with pure rGO film, which is also attributed to the higher electrical conductivity and porous hierarchical structure of the $\mathrm{rGO} / \mathrm{Ti}_{2} \mathrm{CT}_{\mathrm{r}}$ electrode. The discharge/charge capacity of $\mathrm{rGO} / \mathrm{Ti}_{2} \mathrm{CT}_{\mathrm{r}}$ film was observed at different current density, as shown in Figure $5 f$. The $\mathrm{rGO} / \mathrm{Ti}_{2} \mathrm{CT}_{\mathrm{r}}$ film electrodes exhibited good specific capacities even at high rates. The corresponding discharge capacities at 50 $100,250,500,1000$, and $2000 \mathrm{~mA} \mathrm{~g}^{-1}$ are 853, 700, 558, 482, 401 , and $325 \mathrm{mAh} \mathrm{g}^{-1}$, respectively. It's important to stress that the elimination of binder and current collector that becomes possible with our electrodes, further improve the development process of Li-ion batteries. 
(a)
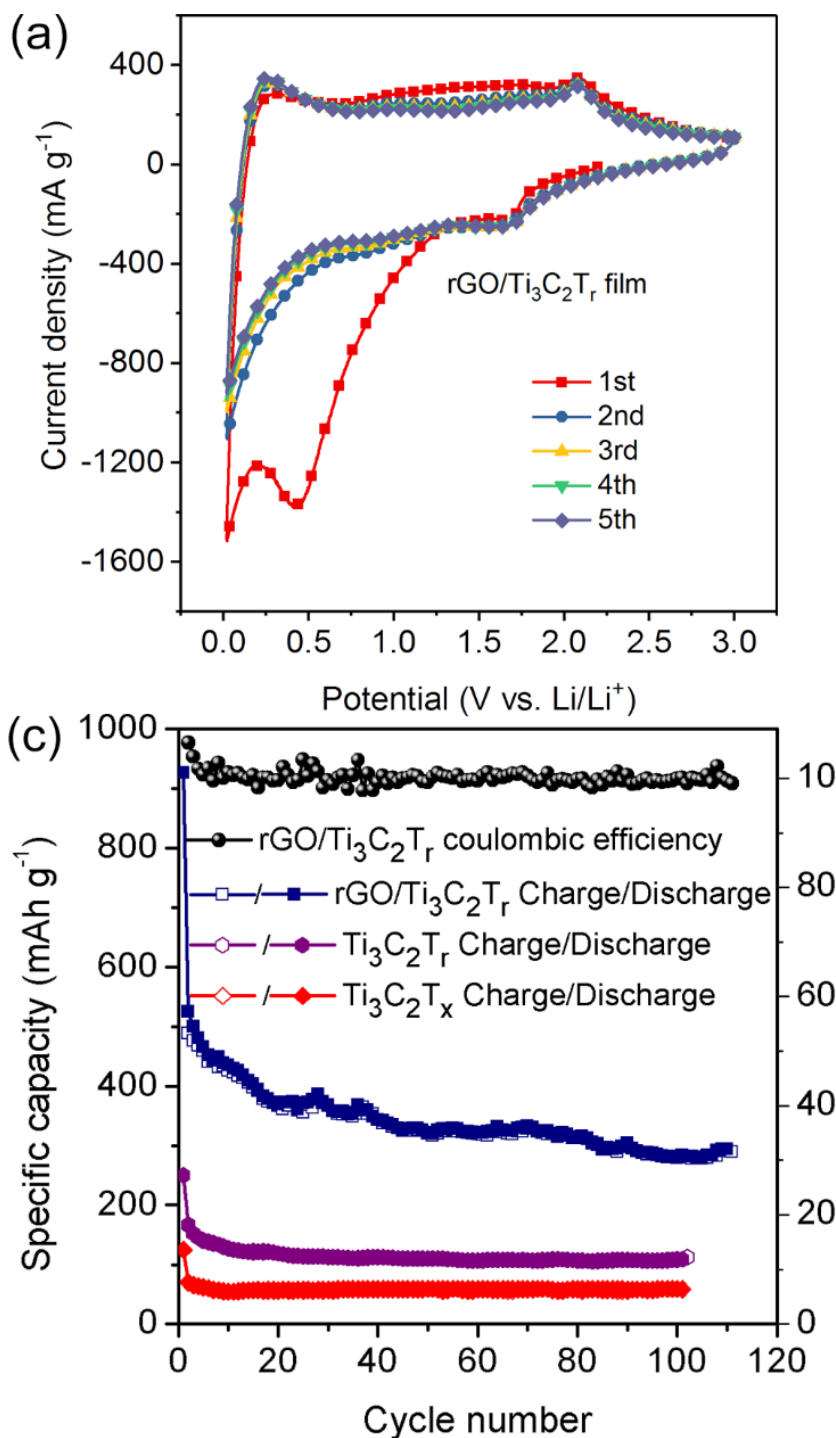

(b)

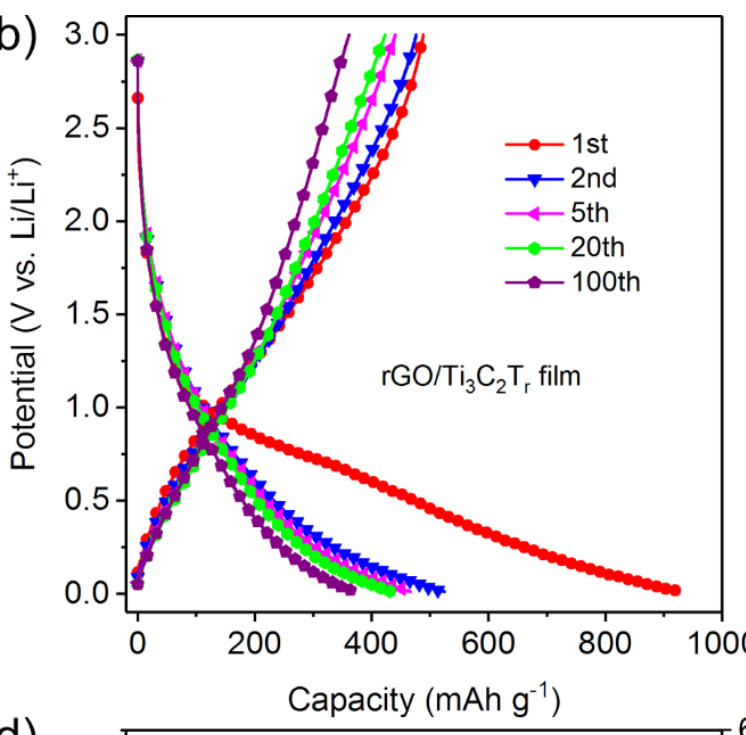

(d)
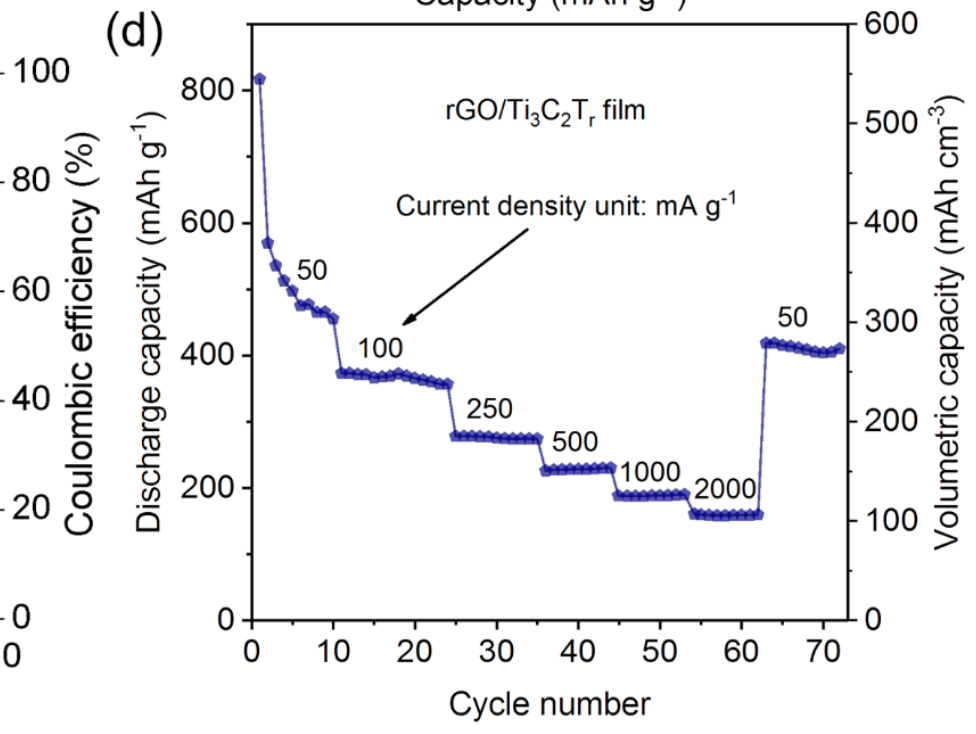

Figure 6. a) $\mathrm{CV}$ curves of $\mathrm{rGO} / \mathrm{Ti}_{3} \mathrm{C}_{2} \mathrm{~T}_{\mathrm{r}}$ electrode at a scan rate of $0.5 \mathrm{mV} \mathrm{s}^{-1}$. b) Charge-discharge profiles of rGO/Ti ${ }_{3} \mathrm{C}_{2} \mathrm{~T}_{\mathrm{r}}$ electrode at different cycles with a current density of $0.1 \mathrm{~A} \mathrm{~g} \mathrm{~g}^{-1}$. c) Cycling performance and coulombic efficiency at a current density of $0.1 \mathrm{~A} \mathrm{~g}^{-1}$. d) Rate performance of hybrid rGO/Ti $\mathrm{C}_{2} \mathrm{~T}_{\mathrm{r}}$ electrode.

Table 1. Comparison of the electrochemical performance of various MXene-based anode materials for Li-ion storage

\begin{tabular}{|c|c|c|c|c|}
\hline Sample & Current density $\left(\mathrm{A} \mathrm{g}^{-1}\right)$ & Cycle number & Reversible capacity $\left(\mathrm{mAh} \mathrm{g}^{-1}\right.$ ) & Reference \\
\hline $\mathrm{Ti}_{2} \mathrm{CT}_{\mathrm{x}}$ anode material & 0.12 & 80 & 110 & [19] \\
\hline $\mathrm{Ti}_{3} \mathrm{C}_{2} \mathrm{~T}_{x}$ paper & 0.4 & 100 & 400 & [20] \\
\hline $\mathrm{Ti}_{3} \mathrm{C}_{2} \mathrm{~T}_{\mathrm{x}} / \mathrm{rGO}$ films & 0.1 & 100 & 280 & [29] \\
\hline $\mathrm{Ti}_{2} \mathrm{CT}_{\mathrm{x}}$ & 0.14 & 100 & 140 & [18] \\
\hline $\mathrm{Ti}_{3} \mathrm{C}_{2} \mathrm{~T}_{x} / \mathrm{CNT}$ paper & 0.6 & 100 & 600 & [37] \\
\hline $\mathrm{Ti}_{3} \mathrm{C}_{2} \mathrm{~T}_{\mathrm{x}}$ disc & 0.03 & 50 & 110 & [38] \\
\hline $\mathrm{Ti}_{3} \mathrm{C}_{2} \mathrm{~T}_{\mathrm{x}}$ & 0.12 & 100 & 124 & [39] \\
\hline $\mathrm{rGO} / \mathrm{Ti}_{2} \mathrm{CT}_{\mathrm{r}}$ film & 0.1 & 100 & 700 & This work \\
\hline $\mathrm{rGO} / \mathrm{Ti}_{3} \mathrm{C}_{2} \mathrm{~T}_{\mathrm{r}}$ film & 0.1 & 100 & 305 & This work \\
\hline
\end{tabular}


This simple and effective method can also be applied for treating other MXenes and fabricating other rGO/MXene films. In this work, $\mathrm{rGO} / \mathrm{Ti}_{3} \mathrm{C}_{2} \mathrm{~T}_{\mathrm{r}}$ films were also fabricated using the similar method. Additionally, the effect of the thermal treatment on the electrochemical performance of $\mathrm{Ti}_{3} \mathrm{C}_{2} \mathrm{~T}_{\mathrm{x}}$ is evaluated. As shown in Figure S5a, c, owing to the removal of surface group $(-\mathrm{OH})$, the CV curves of $\mathrm{Ti}_{3} \mathrm{C}_{2} \mathrm{~T}_{\mathrm{r}}$ presented pseudo-rectangular shape without obvious lithiation and delithiation peaks in comparison to $\mathrm{Ti}_{3} \mathrm{C}_{2} \mathrm{~T}_{\mathrm{x}}$. After removal of the termination groups $(-\mathrm{OH})$ on $\mathrm{Ti}_{3} \mathrm{C}_{2} \mathrm{~T}_{\mathrm{x}}$, the reversible capacity (at current density of $0.1 \mathrm{~A} \mathrm{~g}^{-1}$ ) increased from $55 \mathrm{mAh} \mathrm{g}^{-1}$ of $\mathrm{Ti}_{3} \mathrm{C}_{2} \mathrm{~T}_{\mathrm{x}}$ to $125 \mathrm{mAh} \mathrm{g}^{-1}$ of $\mathrm{Ti}_{3} \mathrm{C}_{2} \mathrm{~T}_{\mathrm{r}}$ (Figure S5b, $\mathrm{d}$ and Figure $6 \mathrm{c}$ ). Furthermore, $\mathrm{rGO} / \mathrm{Ti}_{3} \mathrm{C}_{2} \mathrm{~T}_{\mathrm{r}}$ film was also fabricated and its electrochemical properties were evaluated using $\mathrm{Li}$ ion half-cells. Combining $\mathrm{Ti}_{3} \mathrm{C}_{2} \mathrm{~T}_{\mathrm{r}}$ with rGO nanosheets, the CV profiles of the $\mathrm{rGO} / \mathrm{Ti}_{3} \mathrm{C}_{2} \mathrm{~T}_{\mathrm{r}}$ film (Figure 6a) showed a pseudo-rectangular shape, without obvious lithiation and delithiation peaks, which is similar to the case of $\mathrm{rGO} / \mathrm{Ti}_{2} \mathrm{CT}_{\mathrm{r}}$ film. The charge/discharge profiles (Figure $6 \mathrm{~b}$ ) were sloping over the potential range of $0.01-3 \mathrm{~V} \mathrm{vs}$. $\mathrm{Li}^{+} / \mathrm{Li}$. At current density of $0.1 \mathrm{~A} \mathrm{~g}$ ${ }^{1}$, the first-cycle discharge capacity was approximately $930 \mathrm{mAh}$ $\mathrm{g}^{-1}$ (Figure 6c). After the first cycle, the capacity gradually decreased with increasing cycle number and remained at 305 $\mathrm{mAh} \mathrm{g}^{-1}$ after 100 cycles. The first-cycle irreversibility, and initial capacity drop, can be attributed to the formation of a SEI layer and possible irreversible reactions between $\mathrm{Li}$ ions and electrode materials. The $\mathrm{rGO} / \mathrm{Ti}_{3} \mathrm{C}_{2} \mathrm{~T}_{\mathrm{r}}$ film electrodes exhibited good specific capacities even at high rates (Figure $6 \mathrm{~d}$ ). At $50 \mathrm{~mA} \mathrm{~g}^{-1}$, a capacity of $480 \mathrm{mAh} \mathrm{g}^{-1}$ was achieved. Capacities of approximately 230 $\mathrm{mAh} \mathrm{g}^{-1}$ at $500 \mathrm{~mA} \mathrm{~g}^{-1}$ and approximately $160 \mathrm{mAh} \mathrm{g}^{-1}$ at $2000 \mathrm{~mA}$ $\mathrm{g}^{-1}$ were observed. As shown in Table 1, compared with other MXene-based anode materials, thermal reduced porous rGO/MXene films exhibit competitive capacities. Therefore, the results above demonstrate that the $\mathrm{rGO} / \mathrm{MXene}$ electrodes can be used as promising flexible anodes for Li-ion storage. They can be fabricated by vacuum-assisted filtration, spray coating or other methods, followed by thermal reduction under vacuum or in an inert environment, promoting the applications of MXene-based anode materials in Li-ion batteries and capacitors.

\section{Conclusions}

Flexible freestanding $\mathrm{rGO} / \mathrm{Ti}_{2} \mathrm{CT}_{\mathrm{r}}$ and $\mathrm{rGO} / \mathrm{Ti}_{3} \mathrm{C}_{2} \mathrm{~T}_{\mathrm{r}}$ film electrodes were fabricated by vacuum-assisted filtration followed by thermal reduction. The surface functional groups of MXenes and GO can be removed at the same time during annealing, resulting in an improved contact and electronic transport between MXene and rGO nanosheets. rGO can act as a conductive binder to link the separated layers of MXenes and connect the MXene particles, improving the conductivity of the anode. In turn, the MXene particles impede the agglomeration of rGO nanosheets. It has been demonstrated that flexible freestanding film electrodes with enhanced electrochemical performance for Li-ion storage can be produced by combining MXene with rGO. They exhibit good reversible capacity, improved coulombic efficiency, excellent cycling stability, and rate performance. At current density of $0.1 \mathrm{~A}$ $\mathrm{g}^{-1}$, reversible capacities of $700 \mathrm{mAh} \mathrm{g}^{-1}$ and $305 \mathrm{mAh} \mathrm{g}^{-1}$ were recorded for $\mathrm{rGO} / \mathrm{Ti}_{2} \mathrm{CT}_{\mathrm{r}}$ and $\mathrm{rGO} / \mathrm{Ti}_{3} \mathrm{C}_{2} \mathrm{~T}_{\mathrm{r}}$, respectively. Furthermore, the terminal $-\mathrm{OH}$ groups on MXenes can be removed without phase transformation by thermal treatment at $573 \mathrm{~K}$ in vacuum, resulting in improved electrical conductivity and electrochemical performance of $M X e n e s\left(\mathrm{Ti}_{2} \mathrm{CT}_{\mathrm{x}}\right.$ and $\left.\mathrm{Ti}_{3} \mathrm{C}_{2} \mathrm{~T}_{\mathrm{x}}\right)$ due to the more efficient charge-transfer process. These results will facilitate rapid development and applications of MXene-based electrodes in Li-ion capacitors and batteries.

\section{Experimental Section}

\section{Synthesis of $\mathrm{Ti}_{2} \mathrm{AIC}$}

$\mathrm{Ti}_{2} \mathrm{AIC}$ powder was synthesized by pressureless sintering the mixed powders of titanium (Aladdin Reagent, -325 mesh, 99.8\%), aluminum (Aladdin Reagent, 325 mesh, 99.5\%), and graphite (Aladdin Reagent, crystalline, -325 mesh, 99\%) in a molar ratio of $2: 1.1: 1$ at $1300{ }^{\circ} \mathrm{C}$ for $40 \mathrm{~min}$. After sintering, the product was milled and sieved through a 400 mesh sieve producing powder with particle size less than $38 \mu \mathrm{m}$.

Synthesis and thermal treatment of $\mathrm{Ti}_{2} \mathrm{CT}_{\mathbf{x}}$

Concentrated $\mathrm{HCl}$ was diluted with distilled water to produce a $6 \mathrm{M}$ solution (30 $\mathrm{ml}) .2 \mathrm{~g} \mathrm{LiF}$ was added to the solution, with stirring for $30 \mathrm{~min}$ using a magnetic Teflon stir bar to dissolve the salt. $2 \mathrm{~g}$ of $\mathrm{Ti}_{2} \mathrm{AlC}$ powder was gradually added to the mixed solution to avoid the violent exothermic reaction. The suspension was held at $40{ }^{\circ} \mathrm{C}$ for $12 \mathrm{~h}$. After that the mixture was washed about 4 times through repeated procedure of distilled water, centrifugation, and decanting, until the $\mathrm{pH}$ of supernatant reaches a $\mathrm{pH}$ of approximately 6 . The final product was filtered with a small amount of water. Then the wet sediment was dried in a desiccator under vacuum at room temperature to obtain $\mathrm{Ti}_{2} \mathrm{CT}_{x}$ MXene powder. The asprepared $\mathrm{Ti}_{2} \mathrm{CT}_{x}$ was then calcined at $300{ }^{\circ} \mathrm{C}(573 \mathrm{~K})$ in vacuum for $5 \mathrm{~h}$, and renamed as $\mathrm{Ti}_{2} \mathrm{CT}_{\mathrm{r}}$. A similar procedure was used to prepare $\mathrm{Ti}_{3} \mathrm{C}_{2} \mathrm{~T}_{\mathrm{r}}$. The experimental details of synthesis of $\mathrm{Ti}_{3} \mathrm{C}_{2} \mathrm{~T}_{x}$ can be seen in the supporting information.

\section{Preparation of porous $\mathrm{rGO} / \mathrm{Ti}_{2} \mathrm{CT}_{\mathrm{r}}$ and $\mathrm{rGO} / \mathrm{Ti}_{3} \mathrm{C}_{2} \mathrm{~T}_{\mathrm{r}}$ films}

Graphite oxide was prepared using a modified Hummer's method. ${ }^{[40]}$ The GO colloidal suspension ( $1 \mathrm{mg} \mathrm{mL}^{-1}$ ) was obtained by exfoliating graphite oxide via sonication for $1 \mathrm{~h}$. The hydrophilic $\mathrm{Ti}_{2} \mathrm{CT}_{\mathrm{x}}$ was dispersed in water by sonication, producing a stable $\mathrm{Ti}_{2} \mathrm{CT}_{\mathrm{x}}$-water dispersion $\left(1 \mathrm{mg} \mathrm{mL}^{-1}\right)$. The GO-water and 
$\mathrm{Ti}_{2} \mathrm{CT}_{\mathrm{x}}$-water dispersions were mixed to obtain a $\mathrm{GO} / \mathrm{Ti}_{2} \mathrm{CT}_{\mathrm{x}}$ hybrid colloidal suspension with $\mathrm{GO} / \mathrm{Ti}_{2} \mathrm{CT}_{\mathrm{x}}$ mass ratio of $3: 1$. Then the hybrid suspension was vacuum-filtered through a cellulose filter (diameter: $5 \mathrm{~cm}$; pore size: $0.22 \mu \mathrm{m}$ ), followed by drying in air. The obtained $\mathrm{GO} / \mathrm{Ti}_{2} \mathrm{CT}_{\mathrm{x}}$ films could be easily peeled off from the cellulose filter. Afterwards, the $\mathrm{GO} / \mathrm{Ti}_{2} \mathrm{CT}_{\mathrm{x}}$ samples were thermally treated at $573 \mathrm{~K}$ for $5 \mathrm{~h}$ under vacuum to obtain freestanding $\mathrm{rGO} / \mathrm{Ti}_{2} \mathrm{CT}_{\mathrm{r}}$ films. During the thermal reduction process, the dielectric oxygen-containing functional groups on the surface of $\mathrm{Ti}_{2} \mathrm{CT}_{\mathrm{x}}$ and $\mathrm{GO}$ can be removed at the same time, resulting in improved conductivity between $\mathrm{Ti}_{2} \mathrm{CT}_{\mathrm{r}}$ and $\mathrm{rGO}$ nanosheets. The $\mathrm{rGO} / \mathrm{Ti}_{3} \mathrm{C}_{2} \mathrm{~T}_{\mathrm{r}}$ films were fabricated by a similar method.

\section{Electrode preparation and electrochemical tests in lithium half-cells} $\mathrm{rGO} / \mathrm{MXene}$ films ( $\mathrm{rGO} / \mathrm{Ti}_{2} \mathrm{CT}_{\mathrm{r}}$ and $\mathrm{rGO} / \mathrm{Ti}_{3} \mathrm{C}_{2} \mathrm{~T}_{\mathrm{r}}$ ) themselves can be directly used as working electrodes in the electrochemical tests without using metal current collectors. The working electrodes of $\mathrm{Ti}_{2} \mathrm{CT}_{\mathrm{x}}, \mathrm{Ti}_{2} \mathrm{CT}_{\mathrm{r}}, \mathrm{Ti}_{3} \mathrm{C}_{2} \mathrm{~T}_{\mathrm{x}}$ and $\mathrm{Ti}_{3} \mathrm{C}_{2} \mathrm{~T}_{\mathrm{r}}$ powders were prepared by mixing active materials with carbon black, and polyvinylidene fluoride (PVDF) binder in N-methyl-2-pyrrolidinone (NMP) with a weight ratio of $8: 1: 1$ and the resulting slurries were pasted on a copper foil and then dried at $90{ }^{\circ} \mathrm{C}$ in vacuum. Li-ion half-cells were assembled as coin cells (CR2032 type) with lithium foils as the counter electrodes and polypropylene membranes (3501 Coated PP, Celgard) as separators. The cell assembly was conducted in an argon-filled glove box. The electrolyte was $1 \mathrm{M} \mathrm{LiPF}_{6}$ in a 1:1 mixture of ethylene carbonate (EC) and dimethyl carbonate (DMC). The galvanostatic charge-discharge tests were performed on a LAND battery tester system between 0.01 and $3.0 \mathrm{~V}$ at room temperature. Cyclic voltammetry (CV) measurements at a scan rate of $0.5 \mathrm{mV} \mathrm{s}^{-1}$ within 0-3 $\mathrm{V}$ and electrochemical impedance spectroscopy (EIS) measurements with the frequency ranging from $100 \mathrm{kHz}$ to $10 \mathrm{mHz}$ were conducted with a CHI660D electrochemical workstation. Gravimetric capacities were calculated from the total mass of composite electrodes.

\section{Characterization of materials}

X-ray diffraction (XRD) patterns were recorded with step-scanning powder diffractometer (Smartlab, Rigaku, Japan) using Cu-Ka radiation with a step size of $0.02^{\circ}$ and dwelling time of $0.2 \mathrm{~s}$. The microstructures of the materials were observed by scanning electron microscopy (SEM, MEGALLAN 400) and transmission electron microscopy (TEM, JEOL JEM-2100, Japan), using an accelerating voltage of $200 \mathrm{kV}$. Surface functional groups were examined by Fourier transform infrared spectroscopy (FTIR, Bruker Optiks E55+FRA106, Germany). Thermogravimetric analysis and differential scanning calorimetry analysis (TG-DSC) of MXene were performed using a Setaram Evolution 2400 thermal analyzer with $\alpha-\mathrm{Al}_{2} \mathrm{O}_{3}$ pans under argon flow of $20 \mathrm{~mL} \mathrm{~min}^{-1}$ with a heating rate of $15{ }^{\circ} \mathrm{C} \mathrm{min}-1$ from room temperature to $700{ }^{\circ} \mathrm{C}$. Chemical compositions and oxidation state of the samples were further analyzed using high resolution $\mathrm{X}$-ray photoelectron spectroscopy (XPS) with monochromated Al Ka radiation ( $\mathrm{hv}=1486.6 \mathrm{eV}$ ). Binding energies were referenced to that of free carbon at $284.8 \mathrm{eV}$. The peak fitting was carried out using commercially available software, CasaXPS. Brunauer-Emmett-Teller (BET)-specific surface area were conducted using nitrogen adsorption on a gas sorption analyzer (JWBK132F). The pore size distributions were calculated by the Barrett-JoynerHalenda (BJH) method, and the BJH analysis was done from the desorption branch of the isotherms.

\section{Acknowledgements}

The authors sincerely acknowledge financial support from the General Programs of the National Natural Science Foundation of China (21571080), the national long-term project (WQ20152200273) of "Thousand Talents Plan of Bureau of Foreign Experts Affairs" of People's Republic of China, and the Natural Science Foundation of Jilin province (20170101193JC).

Keywords: MXene $\cdot$ graphene $\cdot$ porous film $\bullet$ flexible anode $\bullet$ Liion storage

[1] M. R. Lukatskaya, B. Dunn, Y. Gogotsi, Nat. Commun. 2016, 7, 126477.

[2] D. P. Dubal, O. Ayyad, V. Ruiz, P. Gomez-Romero, Chem. Soc. Rev. 2015, 44, 1777-1790.

[3] Y. Gogotsi, ACS Nano 2014, 8, 5369-5371.

[4] M. Q. Zhao, M. Torelli, C. E. Ren, M. Ghidiu, Z. Ling, B. Anasori, M. W. Barsoum, Y. Gogotsi, Nano Energy 2016, 30, 603-613.

[5] W. S. Chang, C. M. Park, J. H. Kim, Y. U. Kim, G. Jeongc, H. J. Sohn, Energy Environ. Sci. 2012, 5, 6895.

[6] L. L. Wang, D. Chen, K. Jiang, G. Z. Shen, Chem. Soc. Rev. 2017, 46, 6764-6815.

[7] J. Y. Liu, X. X. Li, J. R. Huang, J. J. Li, P. Zhou, J. H. Liuad, X. J. Huang, J. Mater. Chem. A 2017, 5, 5977-5994.

[8] J. Xiao, D. Choi, L. Cosimbescu, P. Koech, J. Liu, J. P. Lemmon, Chem. Mater. 2010, 22, 4522-4524.

[9] Z. Deng, H. Jiang, Y. Hu, Y. Liu, L. Zhang, H. Liu, C. Li, Adv. Mater. 2017, 29, 1603020.

[10] H. Huang, S. Gao, A. M. Wu, K. Cheng, X. N. Li, X. X. Gao, J. J. Zhao, X. L. Dong, G. Z. Cao, Nano Energy 2017, 31, 74-83.

[11] P. Wang, R. Wang, J. Lang, X. Zhang, Z. Chen, X. Yan, J. Mater. Chem. A 2016, 4, 9760-9766.

[12] M. Li, F. Pan, E. S. G. Choo, Y. Lv, Y. Chen, J. Xue, ACS Appl. Mater. Interfaces 2016, 8, 6972-6981.

[13] J. Liang, Y. Zhao, L. Guo, L. Li, ACS Appl. Mater. Interfaces 2012, 4 5742-5748.

[14] S. Sun, C. Liao, A. M. Hafez, H. Zhu, S. Wu, Chem. Eng. J. 2018, 338 , 27-45.

[15] B. Anasori, M. R. Lukatskaya, Y. Gogotsi, Nat. Rev. Mater. 2017, 2, 16098.

[16] M. Naguib, O. Mashtalir, J. Carle, V. Presser, J. Lu, L. Hultman, Y. Gogotsi, M. W. Barsoum, ACS Nano 2012, 6, 1322-1331.

[17] J. Luo, X. Tao, J. Zhang, Y. Xia, H. Huang, L. Zhang, Y. Gan, C. Liang, W. Zhang, ACS Nano 2016, 10, 2491-2499.

[18] J. Come, M. Naguib, P. Rozier, M. W. Barsoum, Y. Gogotsi, P. L. Taberna, M. Morcrette, P. Simon, J. Electrochem. Soc. 2012 159, A1368-A1373. [19] M. Naguib, J. Come, B. Dyatkin, V. Presser, P. L. Taberna, P. Simon, M. W. Barsoum, Y. Gogotsi, Electrochem. Commun. 2012, 16, 61-64.

[20] O. Mashtalir, M. Naguib, V. N. Mochalin, Y. Dall'Agnese, M. Heon, M. W. Barsoum, Y. Gogotsi, Nat. Commun. 2013, 4, 1716.

[21] A. Byeon, A. M. Glushenkov, B. Anasori, P. Urbankowski, J. Li, B. W. Byles, B. Blake, K. L. Van Aken, S. Kota, E. Pomerantseva, J. W. Lee, Y. Chen, 
Y. Gogotsi, J. Power Sources 2016, 326, 686-694.

[22] X. Xie, M. Q. Zhao, B. Anasori, K. Maleski, C. E. Ren, J. Li, B. W. Byles, E. Pomerantseva, G. Wang, Y. Gogotsi, Nano Energy 2016, 26, 513-523.

[23] J. Luo, W. Zhang, H. Yuan, C. Jin, L. Zhang, H. Huang, C. Liang, Y. Xia, J. Zhang, Y. Gan, X. Tao, ACS Nano 2017, 11, 2459-2469.

[24] M. Khazaei, A. Ranjbar, M. Arai, T. Sasaki, S. Yunoki, J. Mater. Chem. C 2017, 5, 2488-2503.

[25] Y. Dall'Agnese, M. R. Lukatskaya, K. M. Cook, P. L. Taberna, Y. Gogotsi, P. Simon, Electrochem. Commun. 2014, 48, 118-122.

[26] J. Li, X. Yuan, C. Lin, Y. Yang, L. Xu, X. Du, J. Xie, J. Lin, J. Sun, Adv. Energy Mater. 2017, 7, 1602725.

[27] W. Lv, D. M. Tang, Y. B. He, C. H. You, Z. Q. Shi, X. C. Chen, C. M. Chen, P. X. Hou, C. Liu, Q. H. Yang, ACS nano 2009, 3, 3730-3736.

[28] J. Yan, C. E. Ren, K. Maleski, C. B. Hatter, B. Anasori, P. Urbankowski, A. Sarycheva, Y. Gogotsi, Adv. Funct. Mater. 2017, 27, 1701264.

[29] Z. Ma, X. Zhou, W. Deng, D. Lei, Z. Liu, ACS Appl. Mater. Interfaces 2018, 10, 3634-3643.

[30] E. Pomerantseva, Y. Gogotsi, Nature Energy 2017, 2, 17089.
[31] M. Ghidiu, M. R. Lukatskaya, M. Q. Zhao, Y. Gogotsi, M. W. Barsoum, Nature 2014, 516, 78-81.

[32] Q. Peng, J. Guo, Q. Zhang, J. Xiang, B. Liu, A. Zhou, R. Liu, Y. Tian, J. Am. Chem. Soc. 2014, 136, 4113-4116.

[33] J. Li, Y. Du, C. Huo, S. Wang, C. Cui, Ceram. Int. 2015, 41, 2631-2635. [34] Z. Li, L. Wang, D. Sun, Y. Zhang, B. Liu, Q. Hu, A. Zhou, Mat. Sci. Eng. B 2015, 191, 33-40.

[35] M. Naguib, J. Halim, J. Lu, K. M. Cook, L. Hultman, Y. Gogotsi, M. W. Barsoum, J. Am. Chem. Soc. 2013, 135, 15966-15969.

[36] X. Liu, D. Chao, Y. Li, J. Hao, X. Liu, J. Zhao, J. Lin, H. Fan, Z. Shen, Nano Energy 2015, 17, 43-51.

[37] C. E. Ren, M. Q. Zhao, T. Makaryan, J. Halim, M. Boota, S. Kota, B. Anasori, M. W. Barsoum, Y. Gogotsi, ChemElectroChem 2016, 3, 689-693.

[38] S. J. Kim, M. Naguib, M. Zhao, C. Zhang, H. T. Jung, M. W. Barsoum, Y Gogotsi, Electrochim. Acta 2015, 163, 246-251.

[39] D. Sun, M. Wang, Z. Li, G. Fan, L. Z. Fan, A. Zhou, Electrochem. Commun. 2014, 47, 80-83.

[40] W. S. Hummers Jr., R. E. Offema, J. Am. Chem. Soc. 1958, 80, 1339. 


\section{Entry for the Table of Contents}

\section{FULL PAPER}

Flexible freestanding hybrid rGO/MXene films with enhanced Liion storage capacity are fabricated by vacuum-assisted filtration method followed by a simple thermal treatment. In the hybrid films reduced graphene oxide nanosheets act as a binder, which bridges electrochemically active conducting MXene particles. The effect of the surface functional group $(-\mathrm{OH})$ on $\mathrm{Li}-$ storage performance of MXenes is evaluated.

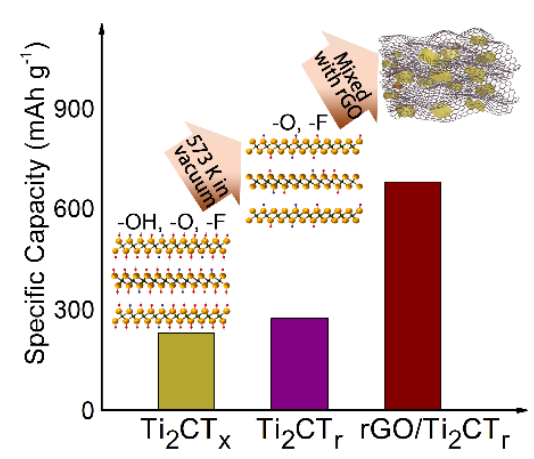

Shuaikai Xu, ${ }^{[a]}$ Yohan Dall'Agnese, ${ }^{[a]}$ Junzhi Li, ${ }^{[a]}$ Yury Gogotsi, ${ }^{*[a, b]}$ and Wei $\operatorname{Han}^{\star[a, c]}$

Thermally reduced graphene/MXene film for enhanced Li-ion storage 